Check for updates

Cite this: RSC Adv., 2018, 8, 8259

Received 6th January 2018

Accepted 16th February 2018

DOI: $10.1039 / c 8 r a 00138 c$

rsc.li/rsc-advances

\section{Synthesis of an unusual quinazoline alkaloid: theoretical and experimental investigations of its structural, electronic, molecular and biological properties $\dagger$}

\author{
Shabir H. Lone, (D) *a Salman Jameel,,$t^{\mathrm{b}}$ Muzzaffar A. Bhat, $\ddagger^{\mathrm{c}}$ Rayees A. Lone, \\ Ray J. Butcher ${ }^{d}$ and Khursheed A. Bhat ${ }^{\star b}$
}

\begin{abstract}
An unusual quinazoline alkaloid (1) was obtained when 2-aminobenzaldehyde was refluxed with pyrrolidine in ethanol for $12 \mathrm{~h}$. The synthesized compound was characterized using spectral data analysis augmented with X-ray and literature precedent. Single crystal analysis depicted four conformations differing slightly in bond angles and bond lengths. Compound 1 crystallizes in a triclinic crystal system with a $P \overline{1}$ space group having two molecules within the unit cell. The experimentally obtained parameters were compared to those obtained theoretically, which depicted a good agreement. Using the DFT/B3LYP/6-31G (d,p) level of theory, HOMO-LUMO energy gap, molecular electrostatic potential (MEP), vibrational (IR) and NMR analyses were carried out. The HOMO-LUMO energy gap allowed the calculation of chemical hardness, chemical inertness, electronegativity and the electrophilicity index of the molecule, which depicted its potential kinetic stability and reactivity. Prediction of activity spectra of the target compound revealed that compound 1 possesses notable antineoplastic activity with $P_{a}=0.884$. The molecule was therefore evaluated against various cancerous cell lines in an in vitro SRB assay which depicted that compound 1 possesses the highest growth inhibition activity against THP-1 cell lines with an $I_{50}$ of $7 \mu \mathrm{M}$.
\end{abstract}

\section{Introduction}

Alkaloids are a very important class of compounds as far as their role in metabolism and activity is concerned. ${ }^{1}$ They are among the oldest drugs used for the treatment of diseases ${ }^{2}$ and are still used as promising therapeutic agents. ${ }^{3,4}$ Deep sea environments are nowadays the focus of research for discovering newer alkaloids with potential therapeutic activities. ${ }^{5-7}$ New alkaloids are also being produced via chemical synthesis and natural product modifications with some of them being more active than the naturally obtained ones. ${ }^{8,9}$ In general alkaloids possess a range of biological activities which include analgesic, antiviral, antimalarial, antineoplastic, antimicrobial, anti-inflammatory, antioxidant antifungal, antibacterial, hemoglobinization

${ }^{a}$ Department of Chemistry, Govt Degree College, Anantnag, Kashmir, 192101, India. E-mail: lone.shabir480@gmail.com

${ }^{b}$ Bioorganic Chemistry Division, Indian Institute of Integrative Medicine, Sanatnagar, Srinagar, Kashmir, India 190005. E-mail: kabhat@iiim.ac.in

'Department of Chemistry, Islamic University of Science and Technology, Awantipora, Kashmir, 192122, India

${ }^{d}$ Department of Chemistry, Howard University, Washington, DC 20059, USA

$\dagger$ Electronic supplementary information (ESI) available. CCDC 1814904 contains the supplementary crystallographic data for $\mathbf{1}$. For ESI and crystallographic data in CIF or other electronic format see DOI: 10.1039/c8ra00138c

$\ddagger$ Both the authors contributed equally. agents of human leukemia cells, effects on the CNS, estrogenic effects etc. ${ }^{\mathbf{1 0 - 2 4}}$ Based on these literature reports of alkaloids and our previous work on the isolation, and synthesis of bioactive compounds, ${ }^{25-37}$ we carried out the synthesis of an unusual selfcondensation product of 2-aminobenzaldehyde by a method reported by Seidal and coworkers. ${ }^{38}$ In order to get deeper insights in to the molecular, structural and biological properties of the synthesized compound, we resorted to spectral, X-ray and DFT analysis. The experimentally obtained parameters were in close agreement to those obtained theoretically. Molecular electrostatic potential and frontier molecular orbital analysis were performed which permitted the calculation of HOMOLUMO energy gap and related parameters. Based on PASS results, the molecule was evaluated against four different human cancer cell lines to explore its biological potential.

\section{Results and discussion}

Reduction of 2-nitrobenzaldehyde using iron powder in glacial acetic acid : ethanol : water system $(2: 2: 1)$ under ultrasonic irradiation conditions for $1.5 \mathrm{~h}$ at $30{ }^{\circ} \mathrm{C}$ yielded the corresponding 2-aminobenzaldehyde. Refluxing 2-aminobenzaldehyde in ethanol with pyrrolidine yielded a reaction mixture containing an unusual self-condensation quinazoline alkaloid (1) (Fig. 1). 
<smiles>O=C(c1ccccc1)c1ccccc1[N+](=O)[O-]</smiles>

Nitrobenzaldehyde<smiles>Nc1ccccc1C=O</smiles>

2-Aminobenzaldehyde

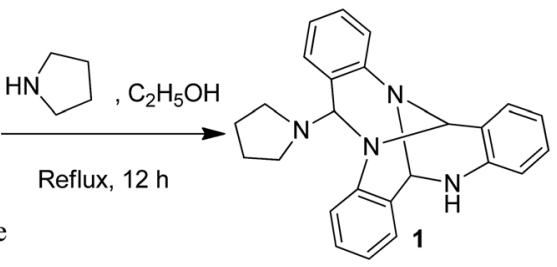

(5S,6S,11bR,12S,13S)-13(pyrrolidin-1-yl)-6,7,11b,13tetrahydro-6,12-[1,2]benzenoquinazolino[3,4]quinazoline

Fig. 1 Synthesis of an unusual quinazoline alkaloid (1).

Pure 1 was obtained when the reaction mixture was subjected to normal phase silica gel column chromatography. It's structure was elucidated while analyzing the spectral data in light of literature. The reaction proceeds via a series of nucleophilic additions of basic nitrogen of pyrrolidine ring on the highly electrophilic aldehyde group of 2-aminobenzaldehyde to give an intermediate which again condenses with two molecules of 2- aminobenzaldehyde to yield compound 1 (Fig. 2). The product was characterized using LC-MS, IR and NMR data analysis. LCMS depicted $m / z$ at 381 assignable to $[\mathrm{M}+\mathrm{H}]^{+}$corresponding to its molecular formula $\mathrm{C}_{25} \mathrm{H}_{24} \mathrm{~N}_{4}$. ${ }^{1} \mathrm{H}$ NMR depicted the presence of 12 aromatic protons assignable to three aromatic rings in the molecule whose presence was further supported by the appearance of $18{ }^{13} \mathrm{C}$ signals in the aromatic region of the

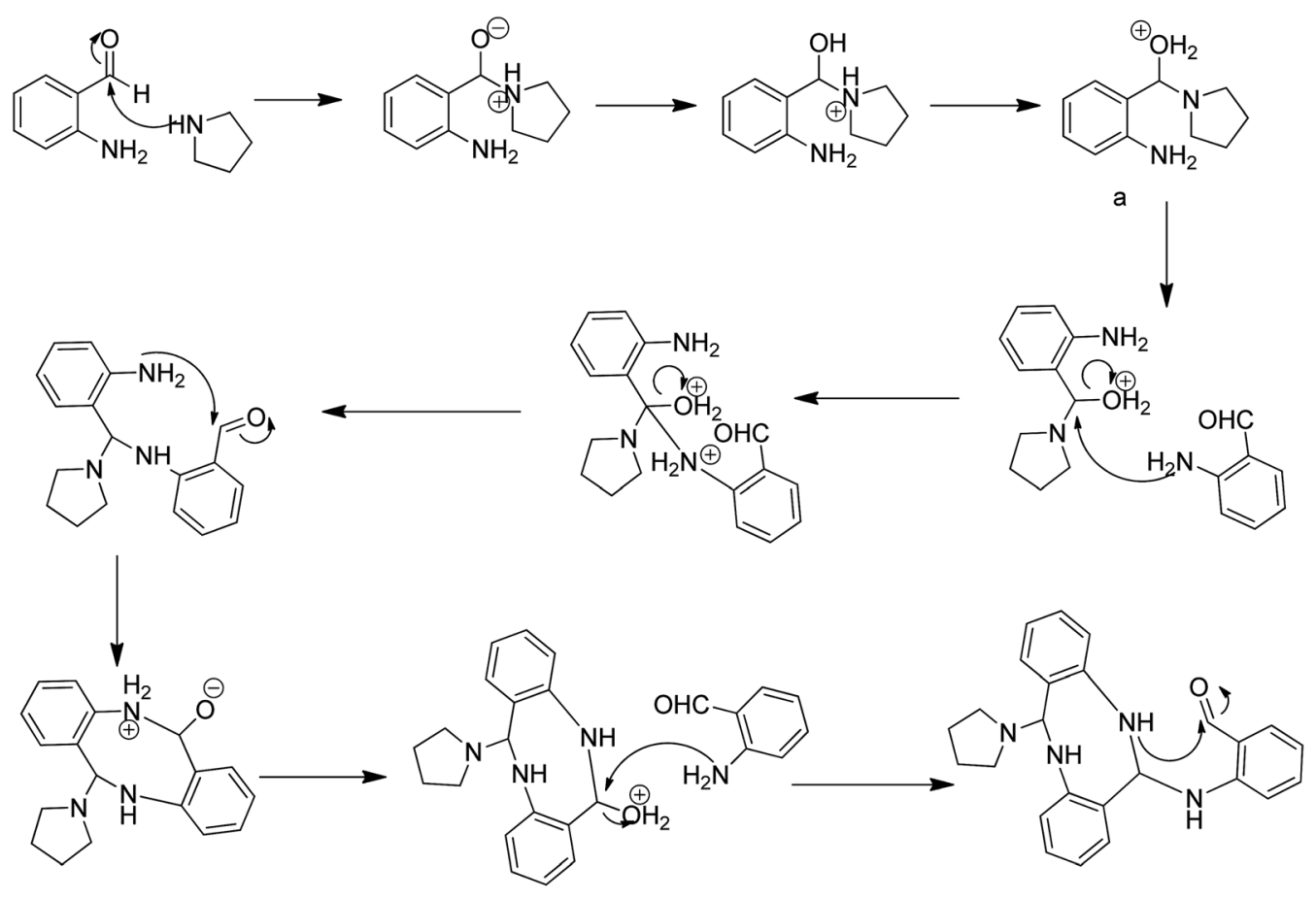

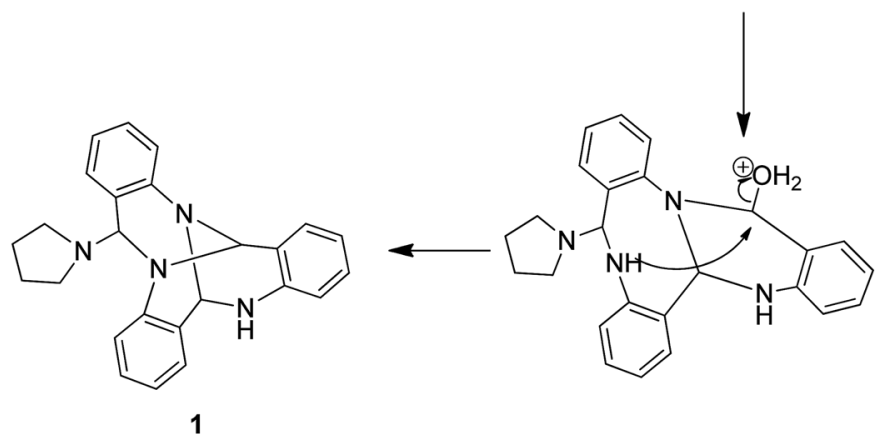

Fig. 2 Mechanism involved in the formation of quinazoline (1). 

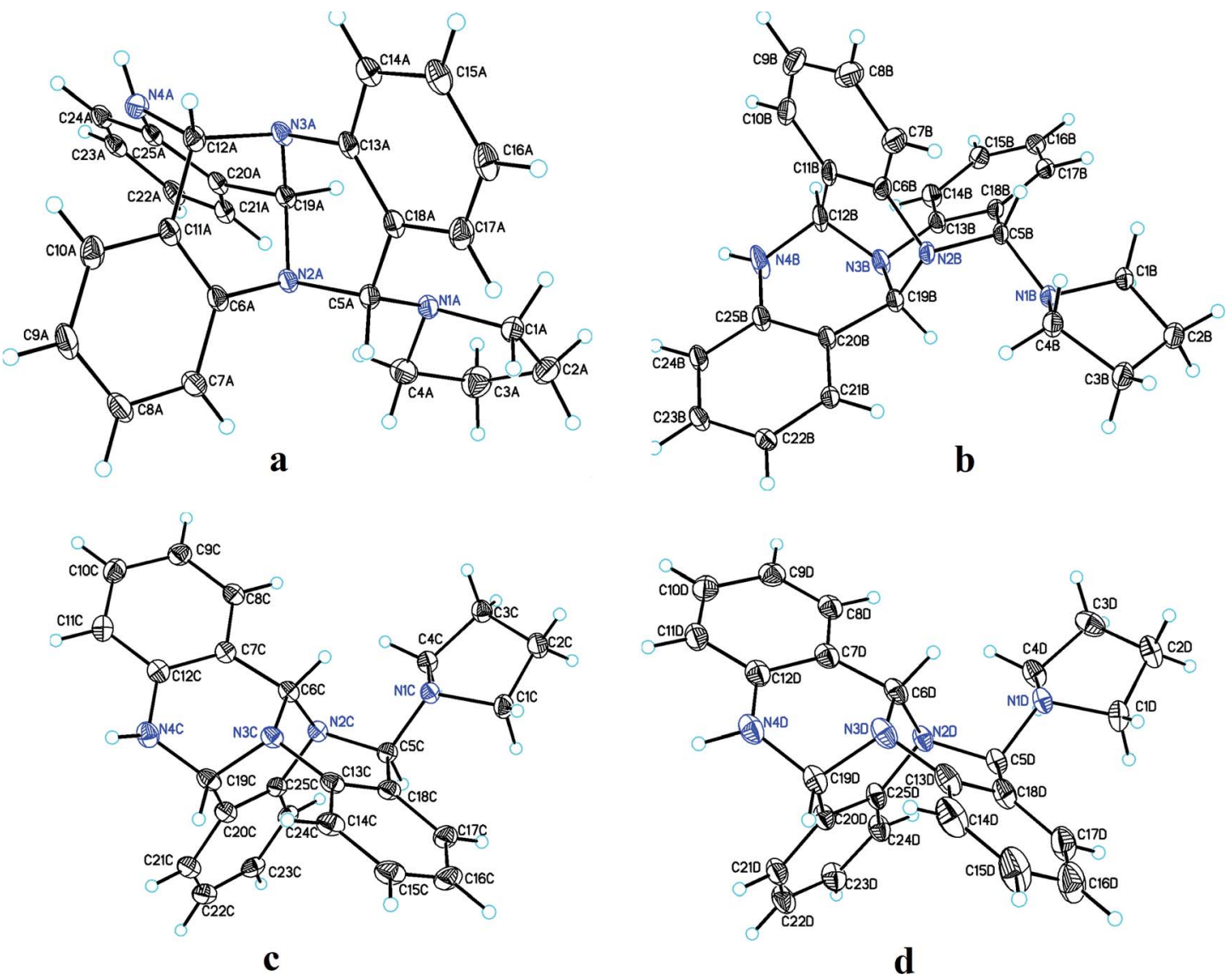

Fig. 3 Four different conformations (a-d) of compound 1 as shown by single crystal X-ray analysis.

Table 1 Crystal data and structure refinement of compound 1

\begin{tabular}{ll}
\hline Identification code & Shelx \\
Empirical formula & $\mathrm{C}_{101} \mathrm{H}_{97} \mathrm{Cl}_{3} \mathrm{~N}_{16}$ \\
Formula weight & 1641.29 \\
Temperature & $153(2) \mathrm{K}$ \\
Wavelength & $1.54184 \AA$ \\
Crystal system & Triclinic \\
Space group & $P \overline{1}$ \\
Unit cell dimensions & $a=12.8967(4) \AA$ \\
& $b=13.9278(3) \AA$ \\
& $c=23.2246(7) \AA$ \\
Volume & $4093.1(2) \AA^{3}$ \\
$Z$ & 2 \\
Density (calculated) & $1.332 \mathrm{mg} \mathrm{m}^{-3}$ \\
Absorption coefficient & $1.497 \mathrm{~mm}^{-1}$ \\
$F(000)$ & 1732 \\
Crystal size & $0.345 \times 0.275 \times 0.233 \mathrm{~mm}^{3}$ \\
Theta range for data collection & 3.492 to $76.684^{\circ}$ \\
Index ranges & $-16 \leq h \leq 16,-11 \leq k \leq 17$, \\
& $-29 \leq l \leq 28$ \\
Reflections collected & 29828 \\
Independent reflections & $16636[R($ int $)=0.0333]$ \\
Completeness to theta $=67.684^{\circ}$ & $99.8 \%$ \\
Absorption correction & Gaussian \\
Max. and min. transmission & 1.000 and 0.322 \\
Refinement method & Full-matrix least-squares on $F^{2}$ \\
Data/restraints/parameters & $16636 / 12 / 1111$ \\
Goodness-of-fit on $F^{2}$ & 1.045
\end{tabular}

molecule. Three downfield ${ }^{1} \mathrm{H}$ NMR singlets at $\delta$ 5.96, 5.29 and $4.52 \mathrm{ppm}$ correspond to $3 \mathrm{CH}$ groups present in the molecule which was supported by three carbon NMR resonances at $\delta 84$, 71 and $64 \mathrm{ppm}$ in its DEPT-NMR. Presence of upfield resonances at 51 and 23 ppm on the downside in DEPT NMR were assignable to four $\mathrm{CH}_{2}$ groups of the pyrrolidine moiety which was supported by upfield resonances corresponding to 8 protons in ${ }^{1} \mathrm{H}$ NMR (see ESI $\dagger$ ). The actual structure was however arrived at using single crystal X-ray analysis (Fig. 3). Pure crystals of 1 were obtained by its crystallization from chloroform and ethanol at room temperature. The molecule crystallizes in a triclinic system with $P \overline{1}$ space group having 2 -units in one unit cell. An X-ray ortep structure of compound $\mathbf{1}$ depicted four different conformations as shown in (Fig. 3). The crystal refinement of the molecule is shown in Table 1 . The four conformers have slight variations among bond lengths and bond angles. Only a few significant differences with regard to bond lengths have been mentioned in Table 2. The characteristic feature of crystal packing view (Fig. 4) is the hydrogen bonding network in the form of $\mathrm{N} \cdots \mathrm{H}-\mathrm{N}, \mathrm{Cl} \cdots \mathrm{H}-\mathrm{C}$. The molecules are interconnected by means of these hydrogen bonds. Another interesting hydrogen bond is the one involving $\mathrm{Cl} \cdots \mathrm{H}-\mathrm{C}$ (Table 3). Since crystallization of the molecule has been carried out in $\mathrm{CHCl}_{3}$ : EtOH solvent, it is likely that one of $\mathrm{CHCl}_{3}$ molecule per unit cell has intruded inside during the process of crystallization providing additional stability to the unit cell. 
Table 2 Comparative analysis of experimentally obtained bond lengths of four conformers with that obtained theoretically (notable ones have been shown, for all refer to ESI file)

\begin{tabular}{|c|c|c|c|c|c|}
\hline $\mathrm{N}(4)-\mathrm{H}(4)$ & 0.80 & 0.88 & 0.86 & 0.96 & 1.0138 \\
\hline$C(3)-C(4)$ & 1.518 & 1.520 & 1.523 & 1.485 & 1.5335 \\
\hline$C(6)-C(7)$ & 1.399 & 1.383 & 1.511 & 1.512 & 1.420 \\
\hline$C(11)-C(12)$ & 1.525 & 1.514 & 1.399 & 1.399 & 1.487 \\
\hline
\end{tabular}

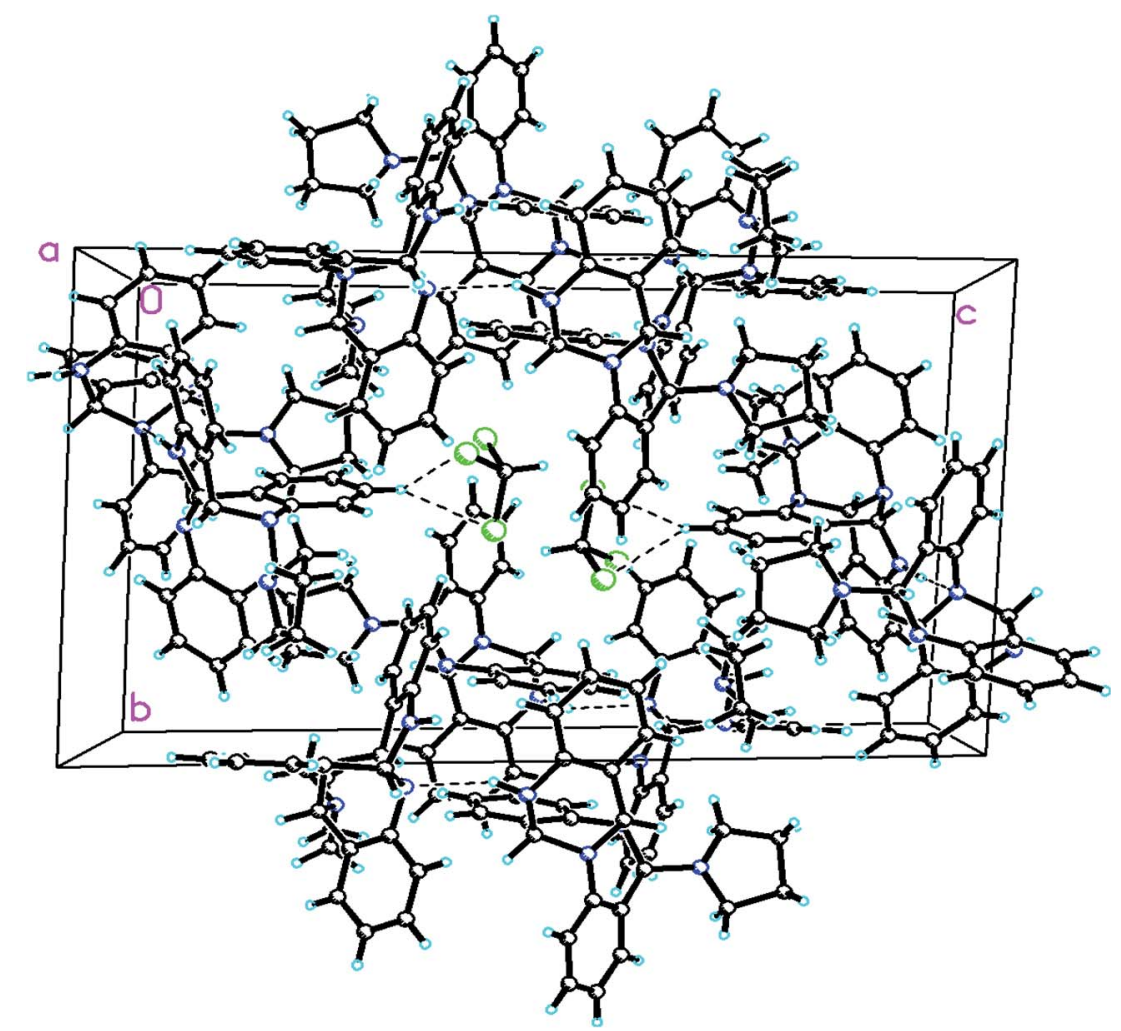

Fig. 4 A perspective view of the crystal packing in the compound 1.

\section{DFT studies}

Theoretical calculations using DFT were performed. This computational method is emerging as an important quantum, chemical tool for studying various chemical problems and is because this versatile method determines energy based on electron density instead of wave-function. The DFT calculations were carried out with a hybrid functional B3LYP (Becke's three parameter hybrid functional) at 6-31G (d,p) level of theory using Gaussian 09 package. The geometries were optimized without imposing any molecular symmetry constraints.

\section{Optimized structures}

The computational chemistry studies in this work aimed at determination of geometric parameters for compound $\mathbf{1}$ and the same were compared with that of the experimentally obtained X-ray data. Table 2 summarizes the selected experimentally obtained (single crystal X-ray analysis) and theoretically calculated parameters (selected bond lengths) using DFT methods. A good approximation of bond lengths while doing optimization using DFT was observed to the experimentally obtained values.

\section{Molecular electrostatic potential surface analysis}

MEPS is a plot of electrostatic potential mapped on to constant potential electron density surface. These surfaces help in predicting reactivity sites towards positively and negatively charged reactants, in studies of biological recognition of one molecule by another as in drug receptor and enzyme substrate interactions as well as hydrogen-bonding interactions. MEP surfaces reveal the size shape and variation of electron density, electronegativity, partial charges and the sites of chemical reactivity with in the 
molecule. ${ }^{39-43}$ Fig. 5 shows MEP surface for compound 1, calculated using DFT/B3LYP/6-31G (d,p) level of theory. The pictorial representation with rainbow colour scheme of electrostatic potential for compound 1 lies in the range of -5.422 a.u to 5.422 a.u. The darkest red regions indicate regions with high electron density (negative potential) which invite electrophilic attacks while as the darkest blue regions indicate regions with low

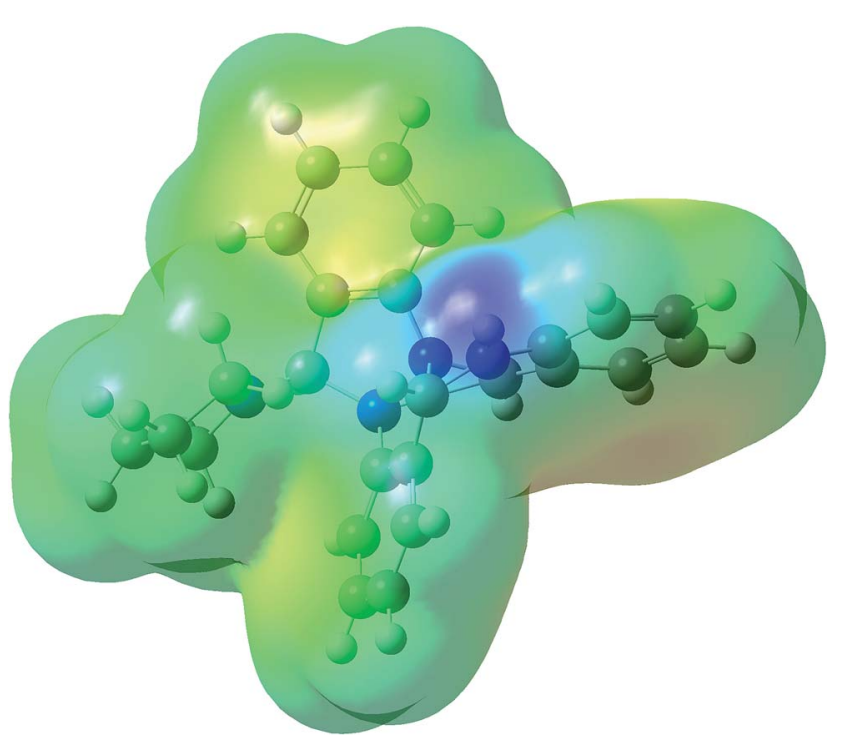

Fig. 5 MEP plot of compound 1 calculated using DFT/B3LYP/6-31G $(d, p)$ level of theory. electron density (positive potential) which allow nucleophiles to approach easily. As can be seen in the MEP for compound 1 the region surrounding the secondary $\mathrm{N}$-atom seems to the darkest blue that is one with lowest electron density, a site more vulnerable to nucleophilic attack. A plausible explanation in this regard is that the lone pair of electrons on $\mathrm{N}$-atom enters in conjugation with the phenyl moiety thereby decreasing the electron density around that $\mathrm{N}$-atom.

\section{Frontier orbital analysis}

Frontier molecular orbitals play important role in the determination of electric and optical properties electronic transitions, kinetic stability. ${ }^{44}$ FMO's of compound 1 were calculated using the Gaussian 09 package at the B3LYP/6-31G (d,p) level of theory. The results are shown in Fig. 6. As can be seen from the figures HOMO and LUMO are located or spread over the regions containing the $\mathrm{N}$-atoms and delocalised over one of the benzene ring with adjacent $\mathrm{NH}$ moiety. In the target compound $\mathbf{1}$, HOMO-LUMO energy gap is $0.094 \mathrm{eV}$. Using HOMO-LUMO energy gap important relative reactivity descriptors like hardness $(\eta)$, chemical potential $(\mu)$, electronegativity $(\chi)$, ionization energy $(I)$ and electron affinity $(A)$ were calculated and are defined as follows: ${ }^{45-49}$

$$
\eta=\frac{(I-A)}{2}, \quad \mu=\frac{-(I+A)}{2}, \quad \chi=\frac{(I+A)}{2}
$$

where $A$ and $I$ represent electron affinity and ionization potential of the molecule, which are in turn obtained from HOMO and

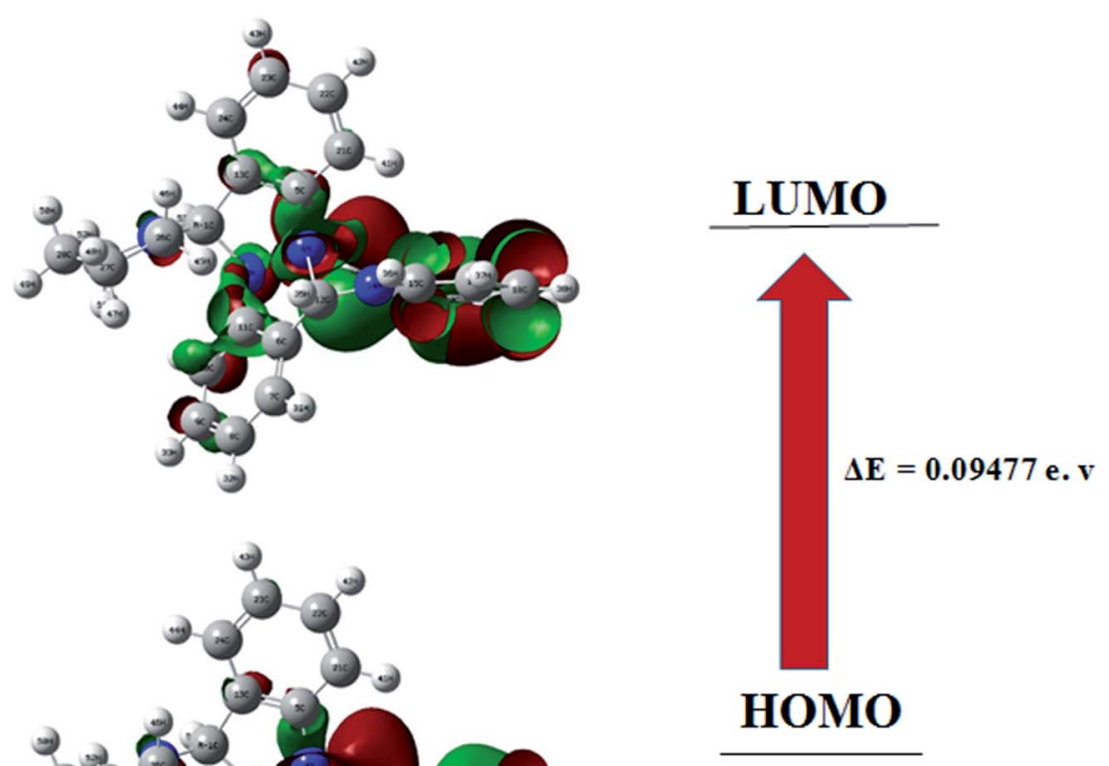

Fig. 6 HOMO-LUMO plots of compound 1. 
Table 3 Hydrogen bonds for compound 1 [A and ${ }^{\circ}$ ]

\begin{tabular}{lllll}
\hline $\mathrm{D}-\mathrm{H} \cdots \mathrm{A}$ & $d(\mathrm{D}-\mathrm{H})$ & $d(\mathrm{H} \cdots \mathrm{A})$ & $d(\mathrm{D} \cdots \mathrm{A})$ & $\angle(\mathrm{DHA})$ \\
\hline $\mathrm{N}(4 \mathrm{~B})-\mathrm{H}(4 \mathrm{~B}) \cdots \mathrm{N}(3 \mathrm{~A})$ & $0.88(5)$ & $2.34(5)$ & $3.143(4)$ & $153(4)$ \\
$\mathrm{N}(4 \mathrm{D})-\mathrm{H}(4 \mathrm{D}) \cdots \mathrm{N}(3 \mathrm{C})$ & $0.96(6)$ & $2.25(6)$ & $3.125(4)$ & $151(4)$ \\
$\mathrm{C}(5 \mathrm{D})-\mathrm{H}(5 \mathrm{DA}) \cdots \mathrm{Cl}(1 \mathrm{~T})$ & 1.00 & 2.96 & $3.718(7)$ & 133.1
\end{tabular}

LUMO energies as $I=-E_{\mathrm{HOMO}}$ and $A=-E_{\mathrm{LUMO}}$ as per Janak theorem ${ }^{50}$ and Perdew et al. ${ }^{51}$ As can be seen the HOMO-LUMO energy gap in compound 1 is just $0.094 \mathrm{eV}$ which indicates its highly reactive nature. Another important factor is the global electrophilicity index $(\omega)$, a global reactivity index that is related to chemical hardness and chemical potential, introduced by Parr et $a l .{ }^{49}$ represented as $\omega=\mu^{2} / 2 \eta$ and was found to be $0.012 \mathrm{eV}$ indicating a poor electrophilic nature of 1 . All the above parameters have been calculated for compound 1 using B3LYP/ 6-31G (d,p) level of theory and are presented in Table 4 as shown:

\section{NMR analysis}

Experimentally ${ }^{1} \mathrm{H}$ and ${ }^{13} \mathrm{C}$ NMR of the title compound was evaluated in $\mathrm{CDCl}_{3}$ solvent using TMS as an internal standard. Theoretically it was calculated in polarisable continuum model with $\mathrm{CHCl}_{3}$ as solvent using GIAO method ${ }^{52}$ involving B3LYP/6$31 \mathrm{G}(\mathrm{d}, \mathrm{p})$ level of theory. Both theoretical and experimental ${ }^{1} \mathrm{H}$ and ${ }^{13} \mathrm{C}$ NMR spectral data are presented in Table 5. Experimental ${ }^{13} \mathrm{C}$ NMR of 1 revealed the presence of 23 resonances assignable to its 25 carbons atoms because of symmetrical nature of pyrrolidine ring. However its theoretical ${ }^{13} \mathrm{C} \mathrm{NMR}$ spectrum displayed all the 25 resonances for 25 carbon atoms. Similarly ${ }^{1} \mathrm{H}$ NMR revealed the presence of 24 protons out of which 12 correspond to aromatic protons of three phenyl rings, three protons as $\mathrm{CH}$ groups, one as $\mathrm{NH}$ and 8 protons assignable to the pyrrolidine moiety. In ${ }^{1} \mathrm{H}$ NMR three $\mathrm{CH}$ protons appeared at 4.52, 5.29 and $5.96 \mathrm{ppm}$ and calculated using DFT at 5.4, 5.8 and $6.2 \mathrm{ppm}$ respectively. Similarly eight protons of the pyrrolidine ring were observed in the range 1.25-3.32 ppm and calculated at 1.37-4.1 ppm for DFT which again revealed a fair agreement. The remaining 12 aromatic protons observed in the range 6.6-7.30 ppm were calculated at 6.6-8.2 ppm for DFT.

Table 4 Calculated energy values for compound 1 using B3LYP/6$31 \mathrm{G}(\mathrm{d}, \mathrm{p})$ level of theory

\begin{tabular}{ll}
\hline Parameter & Compound 1 \\
\hline Energy (au) & -1186.014 \\
Dipole moment (debye) & 3.499 \\
$E_{\text {HOMO }}(\mathrm{eV})$ & -0.139 \\
$E_{\text {LUMO }}(\mathrm{eV})$ & -0.045 \\
$E_{\mathrm{HOMO}-\mathrm{LUMO}}(\mathrm{eV})$ & 0.094 \\
$E_{\mathrm{HOMO}-1}(\mathrm{eV})$ & -0.175 \\
$E_{\mathrm{LUMO}+1}(\mathrm{eV})$ & -0.005 \\
$E_{\text {(HOMO-1)-(LUMO+1) }}(\mathrm{eV})$ & 0.169 \\
Hardness $(\eta)$ & 0.047 \\
Chemical potential $(\mu)$ & 0.092 \\
Electronegativity $(\chi)$ & -0.092 \\
Electrophilicity index $(\omega)$ & 0.012
\end{tabular}

Table 5 Comparsion of theoretical and experimental NMR data of compound 1

\begin{tabular}{|c|c|c|c|}
\hline \multicolumn{2}{|l|}{${ }^{1} \mathrm{H}$ NMR } & \multicolumn{2}{|l|}{${ }^{13} \mathrm{C}$ NMR } \\
\hline Experimental $(\delta \mathrm{ppm})$ & Theoretical & $\begin{array}{l}\text { Experimental } \\
(\delta \mathrm{ppm})\end{array}$ & Theoretical \\
\hline $7.30-6.70(\mathrm{~m}, 12 \mathrm{H})$ & $8.10(\mathrm{~s}, 1 \mathrm{H})$ & 146.08 & 133.86 \\
\hline $5.96(\mathrm{~s}, 1 \mathrm{H})$ & $7.60(\mathrm{~s}, 1 \mathrm{H})$ & 144.23 & 132.90 \\
\hline $5.28(\mathrm{~d}, J=1.5 \mathrm{~Hz}, 1 \mathrm{H})$ & $7.38(\mathrm{~s}, 2 \mathrm{H})$ & 140.08 & 118.62 \\
\hline $4.82(\mathrm{br} \mathrm{s}, 1 \mathrm{H})$ & $7.19(\mathrm{~s}, 2 \mathrm{H})$ & 130.20 & 114.61 \\
\hline $4.52(\mathrm{~s}, 1 \mathrm{H})$ & $7.10(\mathrm{~s}, 2 \mathrm{H})$ & 129.59 & 113.18 \\
\hline $3.32(\mathrm{~m}, 2 \mathrm{H})$ & $6.98(\mathrm{~s}, 1 \mathrm{H})$ & 129.12 & 112.86 \\
\hline $2.85(\mathrm{~m}, 2 \mathrm{H})$ & $6.78(\mathrm{~s}, 1 \mathrm{H})$ & 128.73 & 112.63 \\
\hline \multirow[t]{18}{*}{$2.05-1.92(\mathrm{~m} 4 \mathrm{H})$} & $6.72(\mathrm{~s}, 1 \mathrm{H})$ & 128.48 & 111.98 \\
\hline & $6.65(\mathrm{~s}, 1 \mathrm{H})$ & 128.31 & 110.86 \\
\hline & $6.59(\mathrm{~s}, 1 \mathrm{H})$ & 127.88 & 110.58 \\
\hline & $6.17(\mathrm{~s}, 1 \mathrm{H})$ & 124.97 & 109.86 \\
\hline & $5.83(\mathrm{~s}, 1 \mathrm{H})$ & 124.74 & 108.72 \\
\hline & $5.39(\mathrm{~s}, 1 \mathrm{H})$ & 124.56 & 108.11 \\
\hline & $4.10(\mathrm{~s}, 1 \mathrm{H})$ & 123.93 & 107.89 \\
\hline & $3.53(\mathrm{~s}, 1 \mathrm{H})$ & 123.32 & 106.40 \\
\hline & $3.06(\mathrm{~s}, 1 \mathrm{H})$ & 123.09 & 105.42 \\
\hline & $2.62(\mathrm{~s}, 1 \mathrm{H})$ & 119.98 & 104.73 \\
\hline & $1.89(\mathrm{~s}, 1 \mathrm{H})$ & 117.44 & 97.81 \\
\hline & $1.71(\mathrm{~s}, 1 \mathrm{H})$ & 84 & 94.84 \\
\hline & $1.66(\mathrm{~s}, 1 \mathrm{H})$ & 71.04 & 88.20 \\
\hline & $1.38(\mathrm{~s}, 1 \mathrm{H})$ & 64.12 & 76.45 \\
\hline & & 51.43 & 45.55 \\
\hline & & 51.43 & 36.62 \\
\hline & & 23.76 & 19.07 \\
\hline & & 23.76 & 18.70 \\
\hline
\end{tabular}

\section{IR analysis}

Theoretically a total of 153 normal modes of vibration were obtained for compound 1. However in the desired region between 500 and $4000 \mathrm{~cm}^{-1}$ only 130 such modes were observed. The calculations have been performed within the harmonic approximation for vibrations. Comparision of selected theoretical and experimental modes is presented in Table 6. A fiar agreement is observed between theoretical and experimental IR data. Experimental FT-IR displayed bands in the region $3400-2800 \mathrm{~cm}^{-1}$, 1700-1000 and 1000-500 $\mathrm{cm}^{-1}$. Bands in the region 3400$2800 \mathrm{~cm}^{-1}$ were assignable to $\mathrm{N}-\mathrm{H}$ stretchings, $\mathrm{C}-\mathrm{H}$ stretchings of all the aromatic rings, $\mathrm{C}-\mathrm{H}$ stretchings in which $\mathrm{C}$-atoms are connected to $\mathrm{N}$-atoms and $\mathrm{CH}_{2}$ stretchings of the pyrrolidine moiety. The bands between $1620-1000 \mathrm{~cm}^{-1}$ were assignable to $\mathrm{C}=\mathrm{C}$ stretching vibrations in aromatic rings, $\mathrm{H}-\mathrm{C}=\mathrm{C}$ aromatic ring bend modes, $\mathrm{CH}_{2}$ scissorings, $\mathrm{CH}_{2}$ twistings and $\mathrm{N}-\mathrm{C}$ stretching vibrations. However bands between 900-500 mostly correspond to the torsion modes i.e. distortions in dihedral angles mostly of HCCC, CCCC, NCCC and CNCC type.

\section{PASS and biological evaluation}

After having successfully optimized and calculated various reactivity descriptors for compound 1, using DFT employing the well-known B3LYP/6-31G (d,p) level of theory, we next studied its bioevaluation against various human cancer cell lines. Before carrying out the actual analysis, it was envisaged to 
Table 6 Comparsion of theoretical and experimental IR $\left(\mathrm{cm}^{-1}\right)$ data of compound 1 (selected modes only)

\begin{tabular}{lllll}
\hline $\begin{array}{l}\text { Experimental } \\
\left(\mathrm{cm}^{-1}\right)\end{array}$ & $\begin{array}{l}\text { Theoretical } \\
\left(\mathrm{cm}^{-1}\right)\end{array}$ & $\begin{array}{l}\text { Experimental } \\
\left(\mathrm{cm}^{-1}\right)\end{array}$ & $\begin{array}{l}\text { Theoretical } \\
\left(\mathrm{cm}^{-1}\right)\end{array}$ & $\begin{array}{l}\text { Experimental } \\
\left(\mathrm{cm}^{-1}\right)\end{array}$ \\
\hline 3401 & 3224 & 1465 & 1472 & 960 \\
3062 & 3061 & 1341 & 1336 & 856 \\
$\left(\mathrm{~cm}^{-1}\right)$
\end{tabular}

predict the pharmacological properties of the target compound (1), using an available online PASS. ${ }^{53}$ PASS is an important tool that evaluates the biological activity of a molecule in relation to its structure. It assesses the druglikeness and toxicities of molecules like teratogenicity, carcinogenicity embryogenecity etc. The average accuracy of prediction is about $95 \%$ according to leave-one-out-cross validation (LOOCV) estimation and the probabilities, $P_{\mathrm{a}}$ (probable activity) and $P_{\mathrm{i}}$ (probable inactivity), are values that vary from 0.000 to 1.000 , and generally $P_{\mathrm{a}}+P_{\mathrm{i}} \neq$ 1 as these probabilities are calculated independently. ${ }^{54}$ PASS analysis results for the title compound $\mathbf{1}$ have been enlisted in Table 7. Among the range of activities predicted, the most

Table 7 PASS prediction for the activity spectrum of compound 1 with $P_{a}>0.5$

\begin{tabular}{|c|c|c|}
\hline$P_{\mathrm{a}}$ & $P_{\mathrm{i}}$ & Activity name \\
\hline 0.884 & 0.003 & Antineoplastic enhancer \\
\hline 0.851 & 0.009 & 5 Hydroxytryptamine release stimulant \\
\hline 0.769 & 0.014 & Nicotinic alpha-2-beta-2-receptor antagonist \\
\hline 0.728 & 0.026 & $\begin{array}{l}\text { Nicotinic alpha-6-beta-3-beta-4-alpha-5-receptor } \\
\text { antagonist }\end{array}$ \\
\hline 0.707 & 0.007 & Antihypoxic \\
\hline 0.676 & 0.014 & Thioredoxin inhibitor \\
\hline 0.690 & 0.080 & Phobic disorders treatment \\
\hline 0.605 & 0.003 & Poly(ADP-ribose) polymerase inhibitor \\
\hline 0.637 & 0.052 & Fibrinolytic \\
\hline 0.591 & 0.009 & Atherosclerosis treatment \\
\hline 0.585 & 0.007 & Stroke treatment \\
\hline 0.576 & 0.010 & Octopamine antagonist \\
\hline 0.617 & 0.065 & Antineurotic \\
\hline 0.576 & 0.027 & $(R)-6$-Hydroxynicotine oxidase inhibitor \\
\hline 0.567 & 0.021 & (S)-6-Hydroxynicotine oxidase inhibitor \\
\hline 0.559 & 0.030 & 1,4-Lactonase inhibitor \\
\hline 0.563 & 0.034 & Chloride peroxidase inhibitor \\
\hline 0.579 & 0.054 & Pseudolysin inhibitor \\
\hline 0.589 & 0.068 & $\begin{array}{l}\text { Glycosylphosphatidylinositol } \\
\text { phospholipase D inhibitor }\end{array}$ \\
\hline 0.550 & 0.033 & Alopecia treatment \\
\hline 0.594 & 0.089 & Antieczematic \\
\hline 0.580 & 0.098 & $\begin{array}{l}\text { Testosterone } 17 \text { beta-dehydrogenase } \\
\text { (NADP+) inhibitor }\end{array}$ \\
\hline 0.503 & 0.077 & Calcium channel (voltage-sensitive) activator \\
\hline 0.528 & 0.114 & Nootropic \\
\hline 0.516 & 0.065 & Phthalate 4,5-dioxygenase inhibitor \\
\hline 0.526 & 0.081 & Kidney function stimulant \\
\hline
\end{tabular}

notable is the antineoplastic activity with $P_{\mathrm{a}}$ of 0.884 . To validate the pass results, the title compound was evaluated using sulphorhodamine B (SRB) assay against human-leukemia (THP-1), colon (HCT-116), prostate (PC-3) and lung (A-549) cancer cell lines. It was observed that the title compound possesses a broad spectrum anticancer effect on the cancerous cells with THP-1 cell line as its most easy and soft target. Compound 1 displayed $\mathrm{IC}_{50}$ of $07,12,10$, and $17 \mu \mathrm{M}$ against THP-1, colon (HCT116), prostate (PC-3) and human lung (A-549) cancer cell lines respectively. Since the lowest $\mathrm{IC}_{50}$ is observed against human leukemia cell lines (THP-1) cell-lines, it implies that the usual target of this compound may be leukemia cell lines. However it is equally true that leukemia cell lines are more-sensitive.

\section{Conclusion}

An unusual quinazoline alkaloid (1) was synthesized and characterized using IR and NMR spectral techniques. Single crystal analysis depicted four conformations differing slightly in bond angles and bond lengths. Compound 1 crystallizes in the triclinic crystal system with P-1 space group having two molecules within the unit cell. The experimentally obtained parameters were compared to that obtained theoretically which depicted a good agreement. Using DFT/B3LYP/6-31G (d,p) level of theory, HOMOLUMO energy gap, molecular electrostatic potential surface (MEPS), vibrational and NMR analysis were carried out. HOMOLUMO energy gap was established to carry out the calculation of chemical hardness, chemical inertness, electronegativity and electrophilicity index of the molecule, which depicted the potential kinetic stability and reactivity of the molecule. Prediction of activity spectra of the target compound was carried out which revealed that compound $\mathbf{1}$ possesses notable antineoplastic activity. The pass results were validated by evaluating the molecule against colon (HCT-116), leukemia (THP-1), prostate (PC-3) and human lung (A-549) cancer cell lines respectively in an SRB assay. It was observed that compound 1 possesses remarkable potency against THP-1 cell lines with $\mathrm{IC}_{50}$ of $7 \mu \mathrm{M}$.

\section{Experimental}

\section{General considerations}

2-Nitrobenzaldehyde, iron powder, pyrrolidine etc were procured from Sigma-Aldrich (USA) and used as received. The 
FT-IR spectra of the compound was recorded on Agilent FT-IR spectrometer in $\mathrm{KBr}$ discs $\left(4000-400 \mathrm{~cm}^{-1}\right) .{ }^{1} \mathrm{H},{ }^{13} \mathrm{C}$ NMR spectra were recorded on a Bruker Spectrospin DPX-400 NMR spectrometer at 400.13 and 100.47 respectively using TMS as an internal standard. Mass analysis was carried out using Nexera UHPLC at 130 MPa with SIL-30 AC Nexera autosampler coupled to an LC-MS 8030 tandem mass spectrometer manufactured by Shimadzu Corporation, Kyoto, Japan. The software SADABS was used for absorption correction and SHELXTL for space group, structure determination and refinements. All non-hydrogen atoms were refined anisotropically. All the computations have been carried out at DFT/B3LYP/6-31G (d,p) level of theory using GAUSSIAN 09 software.

\section{Synthesis of 2-aminobenzaldehyde}

2-Aminobenzaldehyde was synthesized by a procedure reported by Gamble et al. ${ }^{55}$ To a suspension of 2-nitrobenzaldehyde $(0.200 \mathrm{~g}, 1.32 \mathrm{mmol})$ in a mixture of glacial acetic acid $(2 \mathrm{~mL})$, ethanol $(2 \mathrm{~mL})$ and water $(1 \mathrm{~mL})$, reduced iron powder $(0.280 \mathrm{~g}$, $5.00 \mathrm{mmol}$ ) was added. The reaction mixture was exposed to ultrasonic irradiation for 1-2 $\mathrm{h}$ at room temperature with continuous TLC monitoring for the completion of reaction. The mixture was filtered to remove the iron residue. The filtrate was partitioned with $2 \mathrm{M} \mathrm{KOH}$ and the basic layer was further extracted with ethyl acetate $(3 \times 25 \mathrm{~mL})$. The combined organic extracts were washed with brine and water and dried under reduced pressure. The crude residue was then chromatographed over silica gel column chromatography using $30 \%$ EtOAc : Hexane as eluent to give 2-aminobenzaldehyde in $80 \%$ yield.

\section{Synthesis of 1}

A $100 \mathrm{~mL}$ round bottomed flask was charged with 2-aminobenzaldehyde (120 mg, $1 \mathrm{mmol})$,ethanol $(2.5 \mathrm{~mL})$ and pyrrolidine $(0.027 \mathrm{~mL}, 0.33 \mathrm{mmol})$ and stirred under reflux conditions and the reaction monitored using TLC analysis till it was complete. After the completion of reaction the solvent of the mixture was evaporated under reduced pressure. The solid residue so obtained, was subjected to silica gel column chromatography and purified using $65: 45$ ethyl acetate : hexane as eluent. Compound $\mathbf{1}$ was obtained as pure yellowish solid.

Yield: $60 \%, \mathrm{mp}: 183{ }^{\circ} \mathrm{C}$, IR $\left(\mathrm{KBr} \mathrm{cm}^{-1}\right)$ : 3401, 3062, 2980, 2830, 2800, 1620, 1560, 1500, 1490, 1465, 1380, 1341, 1301, 1253, 1222, 1120, 1036, 1000, 982, 960, 856, 795, 750, 685, 620, 580, 534, 512, 500. ${ }^{1} \mathrm{H}$ NMR (400 $\left.\mathrm{MHz} \mathrm{CDCl}_{3}\right) 7.30-6.70(\mathrm{~m}$, $12 \mathrm{H}), 5.96(\mathrm{~s}, 1 \mathrm{H}), 5.28(\mathrm{~d}, J=1.5 \mathrm{~Hz}, 1 \mathrm{H}), 4.82(\mathrm{br} \mathrm{s}, 1 \mathrm{H}), 4.52(\mathrm{~s}$, $1 \mathrm{H}), 3.32(\mathrm{~m}, 2 \mathrm{H}), 2.85(\mathrm{~m}, 2 \mathrm{H}), 2.05-1.92(\mathrm{~m} 4 \mathrm{H}),{ }^{13} \mathrm{C}$ NMR $(100$ $\left.\mathrm{MHz}, \mathrm{CDCl}_{3}\right) \delta 146.08,144.23,140.08,130.20,129.59,129.12$, $128.73,128.48,128.31,127.88,124.97,124.74,124.56,123.93$, 123.32, 123.09, 119.98, 117.44, 84.00, 71.04, 64.12, 51.43 (2C), 23.76 (2C). (ESI-MS) at $m / z=381$ for $[\mathrm{M}+\mathrm{H}]^{+}$.

\section{X-ray diffraction study}

Pure rod shaped crystals were selected after recrystallization of the final product (1) from $\mathrm{CHCl}_{3}$ and ethanol solvent. The diffraction data on single crystal of compound $\mathbf{1}$ was collected on a Bruker AXS SMART Apex CCD diffractometer using Mo-K $\alpha$ $(0.71073 \AA)$ radiations at $298 \mathrm{~K}$. The software SADABS $^{56}$ was used for absorption correction and SHELXTL for space group, structure determination and refinements. ${ }^{57,58}$ All non-hydrogen atoms were refined anisotropically.

\section{Density functional theory study}

All the computations are carried out using GAUSSIAN 09 software. ${ }^{59}$ The DFT modeling method, using the hybrid B3LYP ${ }^{60}$ functional was used to calculate theoretical parameters for compound 1 with the basis set combination 6-31 G (d,p). ${ }^{61}$ Geometry optimization was carried out until global minima were achieved. The results of the optimized structure for compound $\mathbf{1}$ are reported in Table 3 and are compared with Xray diffraction results.

\section{SRB cytotoxic assay}

SRB cytotoxic assay was used to screen the compounds for cell cytotoxicity as per the reported procedures. ${ }^{\mathbf{6 2 , 6 3}}$ Various human cancer cell lines, human leukemia (THP-1, at a density of $7 \times$ $10^{3}$ ), human lung carcinoma cell line (A-549, at a density of $8 \times$ $10^{3}$ cells per mL per $100 \mu \mathrm{L}$ per well), human prostate cancer cell line (PC-3, at a density of $8 \times 10^{3}$ cells per $\mathrm{mL}$ per $100 \mu \mathrm{L}$ per well) and human colon cancer cell line (HCT-116, at a density of $1 \times 10^{4}$ cells per $\mathrm{mL}$ per $100 \mu \mathrm{L}$ per well) used in this study were purchased from European collection of cell culture (ECACC) (USA) and seeded in flat-bottomed 96-well plates.

\section{Conflicts of interest}

The authors declare no conflict of interest.

\section{Acknowledgements}

SHL thanks SERB India for the financial support under NPDF scheme (File no: PDF/2016/001690/CS). Salman Jameel thanks CSIR for the Gate Fellowship (Budget Head: P-81101).

\section{References}

1 T. Aniszewski, Sci. Legumes, 1994, 1, 1-24.

2 M. Wink, A short history of alkaloids, in. Alkaloids: Biochemistry, Ecology, and Medicinal Applications, ed. Roberts M. F., and Wink M., Plenum Press, New York, London, 1998, pp. 11-44.

3 S. Bhattacharya, C. Haertel, A. Maelicke and D. Montag, PLoS One, 2014, 9, 89454.

4 Z. Li, Y. N. Geng, J. D. Jiang and W. J. Kong, J. Evidence-Based Complementary Altern. Med., 2014, 2014, 289264.

5 J. Peng, X. Y. Zhang, Z. C. Tu, X. Y. Xu and S. H. Qi, J. Nat. Prod., 2013, 76(5), 983-987.

6 B. Yang, H. M. Tao, X. F. Zhou, X. P. Lin and Y. H. Liu, Nat. Prod. Res., 2013, 27, 433-437.

7 X. W. Yang, G. Y. Zhang, J. X. Ying, B. Yang, X. F. Zhou and A. Steinmetz, Mar. Drugs, 2013, 11(1), 33-39. 
8 X. Guo, Y. Li, C. F. Li, H. M. Luo, L. Z. Wang and J. Qian, Gene, 2013, 527(1), 131-138.

9 R. H. Pouwer, S. M. Deydier, P. V. Le, B. D. Schwartz, N. C. Franken and R. A. Davis, ACS Med. Chem. Lett., 2014, 5(2), 178-182.

10 C. Agyare, G. A. Koffuor, Y. D. Boakye and K. B. Mensah, Pharm. Biol., 2013, 51(4), 418-425.

11 A. A. Boligon, T. F. Kubica, D. N. Mario, T. F. de Brum, M. Piana and R. Weiblen, Acta Physiol. Plant., 2013, 35(7), 2229-2239.

12 E. V. Costa, P. E. O. da Cruz, C. C. de Lourenco, V. R. D. Moraes, P. C. D. Nogueira and M. J. Salvador, Nat. Prod. Res., 2013, 27(11), 1002-1006.

13 J. Hu, X. D. Shi, J. G. Chen, X. Mao, L. Zhu and L. Yu, Food Chem., 2014, 148, 437-444.

14 J. F. Wang, X. P. Lin, C. Qin, S. R. Liao, J. T. Wan and T. Y. Zhang, J. Antibiot., 2014, 67(8), 581-583.

15 Y. Yang, W. J. Zuo, Y. X. Zhao, W. H. Dong, W. L. Mei and H. F. Dai, Planta Med., 2012, 78(17), 1881-1884.

16 C. Iannello, J. Bastida, F. Bonvicini, F. Antognoni, G. A. Gentilomi and F. Poli, Nat. Prod. Res., 2014, 28(10), 704-710.

17 L. Zhang, Z. Hua, Y. Song and C. Feng, Fitoterapia, 2014, 97, 142-147.

18 A. O. Adeoye, B. O. Oguntimein, A. M. Clark and C. D. Hufford, J. Nat. Prod., 1986, 49, 534-537.

19 M. K. Ray, C. Balachandran, V. Duraipandiyan, P. Agastian, S. Ignacimuthu and A. Vijayakumar, Med. Chem. Res., 2013, 22, 823-830.

20 C. Dupont, E. Couillerot, R. Gillet, C. Caron, M. ZechesHanrot and J. F. Riou, Planta Med., 2005, 71, 489-494.

21 S. S. Nazrullaev, I. A. Bessonova and K. S. Akhmed khodzhaeva, Chem. Nat. Compd., 2001, 37, 551-555.

22 M. Goyal and D. Sasmal, J. Ethnopharmacol., 2014, 151, 536542.

23 N. Wang, K. J. Wicht, E. Shaban and T. A. Ngoc, MedChemComm, 2014, 5(7), 927-931.

24 M. Taki, K. Niitu, Y. Omiya, M. Fukuchi, M. Aburada and M. Okada, Planta Med., 2003, 69, 800-803.

25 S. H. Lone, K. A. Bhat, S. Rehman, R. Majeed, A. Hamid and M. A. Khuroo, Bioorg. Med. Chem. Lett., 2013, 3, 4931-4934.

26 S. Naseer, S. H. Lone, J. A. Lone, M. A. Khuroo and K. A. Bhat, J. Chromatogr. B: Biomed. Sci. Appl., 2015, 989, 62-70.

27 S. H. Lone, K. A. Bhat, R. Majeed, A. Hamid and M. A. Khuroo, Bioorg. Med. Chem. Lett., 2014, 24, 1047-1051.

28 S. H. Lone and K. A. Bhat, Tetrahedron Lett., 2015, 56, 19081910.

29 I. Ayoob, S. H. Lone, M. Rahman, O. A. Zargar, R. Bashir, S. Rehman, M. A. Khuroo and K. A. Bhat, ChemistrySelect, 2017, 2, 10153-10156.

30 S. Rehman, K. A. Bhat, S. H. Lone and F. A. Malik, Arabian J. Chem., 2015, DOI: /10.1016/j.arabjc.2015.10.009.

31 S. Rehman, B. Rah, S. H. Lone, R. Rasool, S. Farooq, D. Nayak, N. A. Chikan, S. Chakraborty, A. Behl, D. M. Mondhe, A. Goswami and K. A. Bhat, J. Med. Chem., 2015, 58, 3432-3444.
32 S. H. Lone, K. A. Bhat, F. A. Malik and M. A. Khuroo, Planta Medica International Open, 2016, 3, 51-54.

33 S. H. Lone, S. Rehman and K. A. Bhat, Drug Res., 2017, 67, 111-118.

34 B. A. Dar, S. H. Lone, W. A. Shah and K. A. Bhat, Drug Res., 2016, 66, 427-431.

35 I. Ayoob, Y. M. Hazari, S. H. Lone, S. Rehman, M. A. Khuroo, K. M. Fazili and K. A. Bhat, ChemistrySelect, 2017, 2, 29652968.

36 S. H. Lone, K. A. Bhat, S. Naseer, R. A. Rather, M. A. Khuroo and S. A. Tasaduq, J. Chromatogr. B: Biomed. Sci. Appl., 2013, 940, 135-141.

37 S. H. Lone and K. A. Bhat, Steroids, 2015, 96, 164-168.

38 M. T. Richers, I. Deb, A. Y. Platonova, C. Zhang and D. Seidel, Synthesis, 2013, 45(13), 1430-1748.

39 K. Abhishek, K. S. Ambrish, G. Shashi, M. Neeraj, M. Avijit and B. Goutam, J. Mol. Des., 2015, 1096, 94-101.

40 M. N. Arshad, A. Bibi, T. Mahmood, A. M. Asiri and K. Ayub, Molecules, 2015, 20, 5851-5874.

41 H. Zhou and J. Skolnick, Mol. Pharm., 2012, 9, 1775-1784.

42 E. Scrocco and J. Tomasi, Adv. Quantum Chem., 1979, 11, 115-193.

43 N. Okulik and A. H. Jubert, J. Mol. Des, 2005, 4, 17-30.

44 K. Fukui, T. Yonezawa and H. J. Shingu, J. Chem. Phys., 1952, 20, 722-725.

45 R. A. Costa, P. O. Pitt, M. L. B. Pinheiro, K. M. T. Oliveira, K. S. Salome, A. Barison and E. V. Costa, Spectrochim. Acta, Part A, 2017, 174, 94-104.

46 R. A. Costa, K. M. T. Oliveira, E. V. Costa and M. L. B. Pinheiro, J. Mol. Struct., 2017, 1145, 254-267.

47 N. Özdemir, S. Dayan, O. Dayan, M. Dinçer and N. Kalaycioglu, J. Atom. Mol. Phys., 2013, 11(6), 707-723.

48 R. Parr, Functional Theory of Atoms and Molecules, Oxford University Press, New York, 1989.

49 R. Parr, L. Szentpaly and S. Liu, J. Am. Chem. Soc., 1999, 121, 1922-1924.

50 J. F. Janak, Phys. Rev. B, 1978, 18, 7165.

51 J. P. Perdew, R. G. Parr, M. Levy and J. L. Balduz Jr, Phys. Rev. Lett., 1982, 49, 1691-1694.

52 R. Ditchfield, J. Chem. Phys., 1972, 56, 5688-5691.

53 A. Lagunin, A. Stepanchikova, D. Filimonov and V. Poroikov, Bioinformatics, 2000, 16, 747-748.

54 R. Pramely and T. L. S. Raj, J. Biochem. Technol., 2012, 3, 375379.

55 A. B. Gamble, J. Garner, C. P. Gordon, S. M. J. O'Conner and P. A. Keller, Synth. Commun., 2007, 37, 2777-2786.

56 Brucker SAINT Brucker AXS Inc., Madison Wisconsin, USA, 2002.

57 G. M. Sheldrick, Acta Crystallogr., Sect. A: Found. Crystallogr., 2008, 64, 112-122.

58 G. M. Sheldrick, Acta Crystallogr., Sect. A: Found. Adv., 2015, 71, 3-8.

59 M. J. Frisch, G. W. Trucks, H. B. Schlegel, G. E. Scuseria, M. A. Robb, J. R. Cheeseman, G. Scalmani, V. Barone, B. Mennucci, G. A. Petersson, H. Nakatsuji, M. Caricato, X. Li, H. P. Hratchian, A. F. Izmaylov, J. Bloino, G. Zheng, J. L. Sonnenberg, M. Hada, M. Ehara, K. Toyota, 
R. Fukuda, J. Hasegawa, M. Ishida, T. Nakajima, Y. Honda, O. Kitao, H. Nakai, T. Vreven, J. A. Montgomery Jr, J. E. Peralta, F. Ogliaro, M. Bearpark, J. J. Heyd, E. Brothers, K. N. Kudin, V. N. Staroverov, T. Keith, R. Kobayashi, J. Normand, K. Raghavachari, A. Rendell, J. C. Burant, S. S. Iyengar, J. Tomasi, M. Cossi, N. Rega, J. M. Millam, M. Klene, J. E. Knox, J. B. Cross, V. Bakken, C. Adamo, J. Jaramillo, R. Gomperts, R. E. Stratmann, O. Yazyev, A. J. Austin, R. Cammi, C. Pomelli, J. W. Ochterski, R. L. Martin, K. Morokuma, V. G. Zakrzewski, G. A. Voth, P. Salvador, J. J. Dannenberg, S. Dapprich, A. D. Daniels, O. Farkas, J. B. Foresman, J. V. Ortiz, J. Cioslowski and D. J. Fox, Gaussian 09, B. 01, Gaussian, Inc., Wallingford CT, 2010.

60 (a) A. D. Becke, J. Chem. Phys., 1993, 98, 1372-1378; (b) P. J. Stephens, F. J. Devlin, C. F. Chabalowski and M. J. Frisch, J. Phys. Chem. B, 1994, 98, 11623.
61 (a) A. D. McLean and G. S. Chandler, J. Chem. Phys., 1980, 72, 5639; (b) K. Raghavachari, J. S. Binkley, R. Seeger and J. A. Pople, J. Chem. Phys., 1980, 72, 650; (c) J. P. Blaudeau, M. P. McGrath, L. A. Curtiss and L. Radom, J. Chem. Phys., 1997, 107, 5016; (d) A. J. H. Wachters, J. Chem. Phys., 1970, 52, 1033; (e) P. J. Hay, J. Chem. Phys., 1977, 66, 4377; (f) K. Raghavachari and G. W. Trucks, J. Chem. Phys., 1989, 91, 1062; $(g)$ R. C. Binning Jr and L. A. Curtiss, J. Comput. Chem., 1990, 11, 1206; (h) M. P. McGrath and L. Radom, J. Chem. Phys., 1991, 94, 511; (i) L. A. Curtiss, M. P. McGrath, J. P. Blaudeau, N. E. Davis, R. C. Binning Jr and L. Radom, J. Chem. Phys., 1995, 103, 6104.

62 R. Majeed, M. V. Reddy, P. K. Chinthakindi, P. L. Sangwan, A. Hamid, G. Chashoo, A. K. Saxena and S. Koul, Eur. J. Med. Chem., 2012, 49, 55.

63 G. Chashoo, S. K. Singh, D. M. Mondhe, P. R. Sharma, S. S. Andotra, B. A. Shah, S. C. Taneja and A. K. Saxena, Eur. J. Pharmacol., 2011, 668, 390. 